\title{
Separation and Identification of Many Natural Products from Emblicaofficinalis Fruits and Study of their Antibacterial Activity
}

\author{
Fatimah I. Sultan ${ }^{1}$, Abdel-Monnem S. Khalel ${ }^{2}$, Ayad Ch. Khorsheed ${ }^{3}$ \\ ${ }^{1}$ Lecture, Technical Agricultural College, Plant Production Techniques Dept., Northern Technical University, Mosul, Iraq \\ E.mail: i education@yahoo.com \\ ${ }^{2}$ Prof., Technical Agricultural College, Plant Production Techniques Dept., Northern Technical University, Mosul, Iraq \\ E.mail: drmonnem@ntu.edu.iq \\ ${ }^{3}$ Prof., Education for Girls College, Biology Dept., Mosul University, Mosul, Iraq \\ E.mail: ayad chachaniraq@yahoo.com
}

\begin{abstract}
The active constituents were separated from Emblicaofficinalis fruit, using column chromatography (CC) with solvent system of (pet.ether:ethyl acetate; 5:1) from petroleum ether extract $\left(A_{1}\right)$ and solvent system (chloroform:Methanol; 10:1) from Ethanol extract $\left(A_{2}\right)$. Saponification process was carried out on $\left(A_{1} F_{2}\right)$ to separate many fatty acids and identification of five fatty acids (Heptanoic, Octanoic, Lauric, Palmitic and also cis\& trans Oleic acids) using GLC-analysis. Moreover, acid hydrolysis was also carried out on $\left(A_{2} F_{2}\right)$, to separate many free poles of phenolic compounds, such as (Hydroquinone and Gallic acid) were identified using HPLC-analysis. The active separated compounds under study showed different effects against the microorganisms (m.o), using disc diffusion method turbidity.
\end{abstract}

Keywords-GLC analysis, Emblicaofficinalis, fatty acid, phenolic compounds.

\section{INTRODUCTION}

Emblicaofficinalis (amla) belongs to the familyEuphorbiaceae. It is one of the most often used herb in Ayurveda. It has a reputation as a powerful rejuvenating herb. Amla is a medium-sized deciduous tree with gray bark and reddish wood. It is native to tropical southeastern Asia, particularly in central and southern India, Pakistan, Bangladesh and Sri Lanka. It is commonly cultivated in gardens throughout India and grown commercially as a medicinal fruit. Amla fruit is reputed to have the highest content of vitamin C. the major chemical constituents of amla are phyllemblin, ascorbic acid (vitamin C), gallic acid, tannins, pectin (Priya et al., 2012).Amla is hepatoprotective, anti tumor, antioxidant, antiulcerogenic and antimicrobial against a wide range of bacteria (Sairam et al., 2002; Rajkumar et al., 2014).Amla has been found rich in unsaturated acids. Most predominant polyunsaturated fatty acids like
(Lauric, Myristic, Palmitic, Stearic, Oleic, Linolenic and Linoleic and its rich in phenolic compounds like Ascorbic acid, Gallic acid, Chlorogenicacid, Ellagic acid, Myricetin, Quercetin and Kaempferol (Arora et al., 2011; Bansal et al., 2014).The antimicrobial properties of methanolic seed extract of amla was evaluated against various microbial E. coli, Staph. aureus, K. pneumoniae and $P$. aeruginosa. The sensitivity test for the bacterial species on the methanolicseed extract of amla showed exhibited good activity as similar results (Priya et al., 2012).

\section{MATERIALS AND METHODS}

Amla fruits were collected from local markets of Mosul city then classified and verified by Dr. TalalTaha(a director of the medicinal plants project in Mosul Dam project) according tothe sources of classification.

Preparation of plant extracts:A batch of $50 \mathrm{gm}$ of the ground fruits of amla was Soxhlet extracted for 6-8 hrs. with $1 \mathrm{~L}$ of two solvents (petroleum-ether and ethanol). All these extracts were concentrated to $25 \mathrm{ml}$ on a vacuum rotary evaporator at $50^{\circ} \mathrm{C}$. the crude of each extract was used for further studies.

Fractionation of petroleum-ether and ethanoliccrude extract: $300 \mathrm{mg}$ of each crude extract which was previously prepared was mixed with a small amount of Silica gel $25 \mathrm{gm}$ and then transferred to the top of a prepared Silica gel (60-120 mesh) column. The column was eluted with (pet-ether-ethyl acetate; 5:1) V/V intervals. Dis solved $1 \mathrm{gm}$ of each extract of petroleumether $\mathrm{A}_{1}$ and ethanolic $\mathrm{A}_{2}$ on the basis of amla fruits. Separation of the extract wasperformed using a Silica gel filled column type Silica gel 60 A for flash chromalography filled with $30 \mathrm{gm}$ of gels with petroleum ether-ethylacetateas a solvent $(5: 1 \mathrm{~V} / \mathrm{V})$ and code for P.E for crude petroleum ether extract, two fractions were obtained $\mathrm{A}_{1} \mathrm{~F}_{2}, \mathrm{~A}_{1} \mathrm{~F}_{3}$. The ethanol extract has been filled with solvent chloroform: Methanol 
(10:1 V/V) Ch:M, several fractions were obtained $\mathrm{A}_{1} \mathrm{~F}_{2}$ depending on the similarity of the spots in their positions and shapes on the TLC plate. And for the same solution system used in the column. The parts were evaporated by rotary evaporator RVE under pressure.

Saponification of the extracts: Saponification process was carried out using petroleum ether extract which belongs to $\left(A_{1}\right)$ from (petroleum ether: ethyl acetate) (5:1) to gel $A_{1} F_{2}$ and $\mathrm{A}_{1} \mathrm{~F}_{3}$ as a resulted from column chromatography. Moreover, the fraction of $\mathrm{A}_{1} \mathrm{~F}_{2}$ was also saponified to librate free fatty acids, also acid hydrolysis was done. Also, the crude ethanolic extract was fractionated to (chloroformmethanol) (10:1). The fraction $\mathrm{A}_{2} \mathrm{~F}_{2}$ was subjected to saponification to while the $\mathrm{A}_{2}$ fraction were acid hydrolysed. Alkaline hydrolysis to obtain fatty acid compounds: Petether extracts and the fractions of petroleumether:ethylacetate resulted from column chromatography.A mixture of $10 \mathrm{gm}$ of each pet-ether extract and also the fractions (petroleumether:Ethylacetate) from petroleum ether extracts $\left(\mathrm{A}_{1} \mathrm{~F}_{2}\right)$ and $100 \mathrm{ml}$ of 7-5 M of solution of $\mathrm{KOH}$ in $\mathrm{MeOH}$ :water (3-2) was refluxed in a round bottom flask for $20 \mathrm{~min}$ at $100^{\circ} \mathrm{C}$. The suspension crude extract was allowed to cool down at room temperature, and $100 \mathrm{ml}$ of distilled water was added. The crude was extracted with diethyl ether $(2 \times 100 \mathrm{ml})$ to remove unhydrolysed 1ipid. The hydrolyte was acidified with $20 \%(\mathrm{~V} / \mathrm{V})$ conc. $\mathrm{H}_{2} \mathrm{SO}_{4}$ up to $\mathrm{PH}=2$. the librated fatty acids were extracted with diethyl ether $(2 \times 100 \mathrm{ml})$ (Aruther, 1972).The combined extracts were washed with water and dried over anhydrous sodiumsulfate, filtered and concentrated in vacuum to give 1.2 gm of crude fatty acid compounds.

Preparation of Methyl Esters: $0.1 \mathrm{ml}$ of acetyl chloride was added to $25 \mathrm{ml}$ dry methanol with stirring,. Also, the sample of $0.5 \mathrm{ml}$ of dry fatty acids was added to the above mixture, then boiled under reflux in a water bath for $20 \mathrm{~min}$ and dry closed system, then cooled for analysis by GLC method (Al-Kaisy, 1991).

Acid hydrolysis to separate free pole phenolic compounds: The fractions of (Chloroform:methanol) (10:1) resulted from column chromatography. A mixture of $5 \mathrm{ml}$ of fraction (Chloroform: methanol) from ethanol extracts $\mathrm{A}_{2} \mathrm{~F}_{2}$ and $25 \mathrm{ml}$ of $(1 \mathrm{~N}) \mathrm{HCl}$ was refluxed in around bottom flask for $1 \mathrm{hr}$. at $100^{\circ} \mathrm{C}$. after cooling, the solution was transferred to the separating funnel then $(2 \times 5$ $\mathrm{ml}$ ) of ethyl acetate was added with stirring and after is olation of organic layer from aqueous layer, the organic layer was dried by adding 10 gm of magnesium sulfate for $10 \mathrm{~min}$. The ethyl acetate was concentrated under vacuum rotary evaporates and then kept the free pole of phenolic compounds in glass bottles for further analysis (Harborne, 1998).
GLC-Analysis: The fatty acid methylesters can be obtained either directly by transmethylation of the parent lipids by refluxing for 90 min-with ( $\mathrm{MeOH}$-benzene $\mathrm{H}_{2} \mathrm{SO}_{4}$ ) (20:10:1) or from the free acids by the acetyl Chloride-Methanol. The esters were analysed by using GLC on a packurd 419 equipped with adanl flame ionization detectors at $270^{\circ} \mathrm{C}$ temp. A(2-12 $\mathrm{m} \times 2 \mathrm{~m})$ international diameter column. Packed with $3 \%$ silar $10^{\circ} \mathrm{C}$ on Gas Chrom Q (100-120m) was initially, then raised to $5^{\circ} \mathrm{C}$ for one $\min$ to 20 . The identification of fatty acidswere determined by references to a standard of known composition (Bauer et al., 1966).

HPLC-Analysis: The free pole of phenolic compounds was identified by using HPLC apparatus with shimadzo-2010 AHT after purification by filters with a diameter of 0-1 micrometer, and using $320 \mathrm{~nm}$ wavelength and $1 \mathrm{ml} / \mathrm{min}$ flow rate and (85/ Acetonitrile:15. $\mathrm{H}_{2} \mathrm{O}$ ) as a mobile phase by using the column of $\mathrm{C} 18(4 \times 240 \mathrm{~mm})$ at $30^{\circ} \mathrm{C}$ temperature. The instrument was provided from a Cherey company Naged and all measurements were carried out in the laboratory of University of Mosul.

Antibacterial activities of prepared extracts of amla: The antibacterial effect of these extracts were tested on all studied bacteria according to the method of modified Kirby-Bauer (Adam, 2006) in which the inoculums were prepared in nutrient broth and incubation at $37^{\circ} \mathrm{C}$ for $(18$ 24) hrs. The density of the tested suspensions was adjusted to $0.5 \mathrm{McF}$ arland Standard Muller-Hinton agar plated was inoculated by dipping a sterile cotton swabs in the inoculums the excess inoculums were removed by pressing and rotating the swabs firmly against the side of the tubes above the level of the liquids and the swabs were streaked all over the liquids and the swabs were streaked all over the surface of the solution.

Finally, the inoculums were left to dry for few minutes later $50 \mathrm{ml}$ of each of the prepared extracts were dried and re-dissolved in DMSO and placed in walls $6 \mathrm{~mm}$ in diameter which were placed on the inoculated plates, the antibiotic discs were also placed. The plates were incubated at $37^{\circ} \mathrm{C}$ for (18-24) hrs. the diameter of each zone of inhibition (including the diameter of wells and discs) were measured, recorded and compared with the standard antibiotics (Gentamicin (CN) $10 \mathrm{meg}$, Amikacin (AK) $10 \mathrm{meg}$, ciprofloxacin (10 meg). Also we have used various concentration $(200-50) \mathrm{mg} / \mathrm{cm}^{2}$ of plant extracts under study (Asif, M., 2011).

\section{RESULTS AND DISCUSSION}

During the phytochemical screening and previous studies (Priya et al., 2012; Sairam et al., 2002; Rajkumar et al., 2014) of the amla composition which were mentioned with many fatty acid compounds and many phenolic compounds which were investigated in the fruits of amla. From the study of above we have noticed and identified many fatty acid 
compounds, by using GLC-analysis. Table 1. and Figure 1. and Figure2. showed the presence of five fatty acid compounds within the fraction $\mathrm{A}_{1} \mathrm{~F}_{2}$ they are Heptanoic In this study, major unsaturated fatty acids were found such as Oleic acid in this species, at high percentage (Priya et al., 2012). Oleic acid was also found as a major fatty acid which play an important role in the body as it is combined with omega-3 to many health benefits (Okpako and Ajibesin, 2015). Also two phenolic compounds were identified Table 2. and Figure 3. and Figure 4. in the fruit of amla. The fraction $\mathrm{A}_{2} \mathrm{~F}_{2}$ which were found the column as acid hydrolysis took place to release free phenolic compounds to get HPLC analysis which is explaining as follows. The fraction $\mathrm{A}_{2} \mathrm{~F}_{2}$ was contained Gallic acid with $\mathrm{R}_{\mathrm{t}}(2.048 \mathrm{~min})$ and Hydroquinone $\mathrm{R}_{\mathrm{t}}(2.537 \mathrm{~min})$.The results were similar to previous studies(Bansal et al., 2014; Agarwal et al., 2012). Table 3. and Table 4. and Photos 13. showing the antibacterial activity of amla (fatty acids \& phenolic extract) against some pathogens bacteria (Staphylococcus aureus, Escherichia coli and Salmonella typhimurium).

The results showed that fatty acid extracts $\left(\mathrm{A}_{1} \mathrm{~F}_{2}\right)$ and phenolic compound $\left(\mathrm{A}_{2} \mathrm{~F}_{2}\right)$ at $\left(200 \mathrm{mg} / \mathrm{c}^{3}\right)$ per disc possessed high antibacterial activity against Staph. aureus
(0.0079\%), Octanoic $(0.0138 \%)$, Lauric $(0.0161 \%)$, Palmitic $(0.045 \%)$ and (cis\& trans)Oleic acid $(0.172 \%)$.

and Escherichia coli whereas it was moderately active against Salmonella typhimurium compared with antibiotic compounds (Gentamicin (CN) 10 meg, Amikacin (AK) 10 $\mathrm{meg}$, and Ciprofloxacin (Cip) $10 \mathrm{meg}$ ). From previous studies (Nitiema et al., 2012) we focused on some phenolic compounds action against bacteria involved in cute gastroenteritis diarrhea.

The study (Priya et al., 2012) results by using seeds of amlathat it contain high antibacterial and antioxidant activities and can be further studiedfor the isolation of its bioactive compound. So, the amlaand Cayratiapedata exhibited a potential of in-vitro antimicrobial activity against Helicobacter Pylori which suggest that it may be useful for the treatment of H. Pylori infection (Rajkumar et al., 2014).

Thus, several studies have reported the antimicrobial activities of plant extracts from various parts like leaves, seeds and flowers (Karon et al., 2005; Falleh et al., 2008). These results often pointed out that crude extract possesses low antibacterial activities against enteric bacteria (Karon et al., 2005; Zongo et al., 2011).

Table.1: GLC analysis of amla extracts of fatty acid compounds.

\begin{tabular}{|c|c|c|c|c|c|c|c|c|c|c|}
\hline \multirow{3}{*}{$\begin{array}{c}\text { Extracts } \\
\text { of amla }\end{array}$} & \multicolumn{10}{|c|}{ Fatty acid compounds } \\
\hline & \multicolumn{2}{|c|}{ Heptanoic } & \multicolumn{2}{|c|}{ Octanoic } & \multicolumn{2}{|c|}{ Lauric } & \multicolumn{2}{|c|}{ Palmitic } & \multicolumn{2}{|c|}{ cis \& trans Oleic acid } \\
\hline & $\mathrm{R}_{\mathrm{t}}(\min )$ & Conc. & $\mathrm{R}_{\mathrm{t}}(\min )$ & Conc. & $\mathrm{R}_{\mathrm{t}}(\min )$ & Conc. & $\mathrm{R}_{\mathrm{t}}(\min )$ & Conc. & $\mathrm{R}_{\mathrm{t}}(\min )$ & Conc. \\
\hline $\begin{array}{l}\text { Fraction } \\
\mathrm{A}_{1} \mathrm{~F}_{2}\end{array}$ & 6.999 & 0.0079 & 8.273 & 0.0138 & 12.835 & 0.0161 & 15.558 & 0.0451 & 18.825 & 0.172 \\
\hline
\end{tabular}

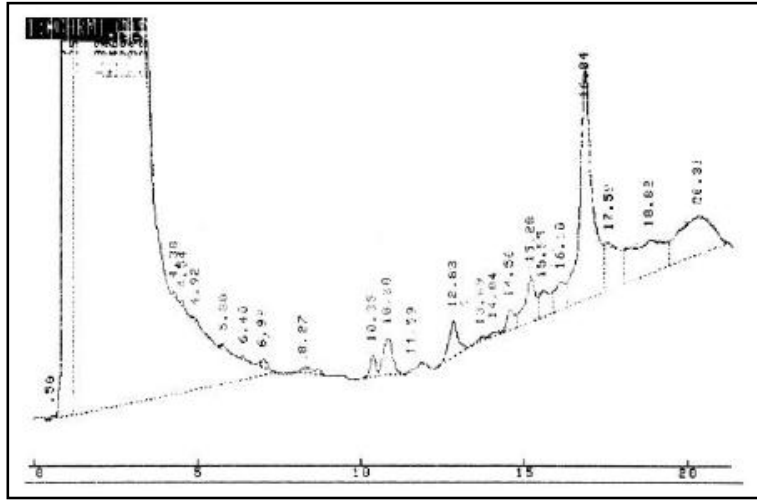

Fraction $\mathrm{A}_{1} \mathrm{~F}_{2}$

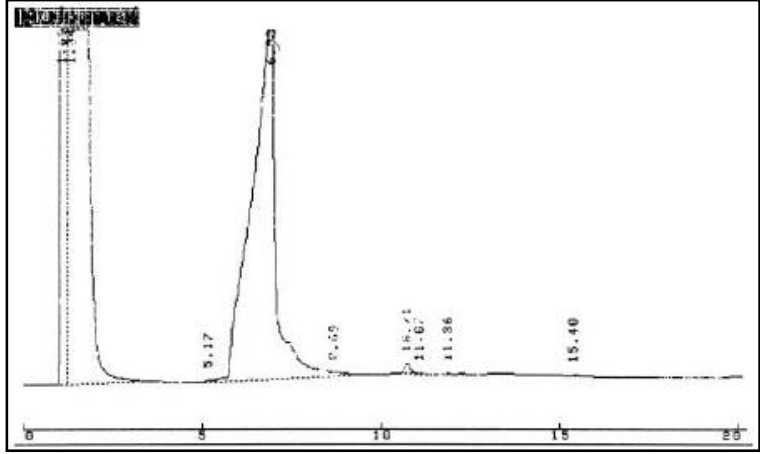

Heptanoic

Fig.1: GLC chromatograms offatty acid compounds presented in amla. 


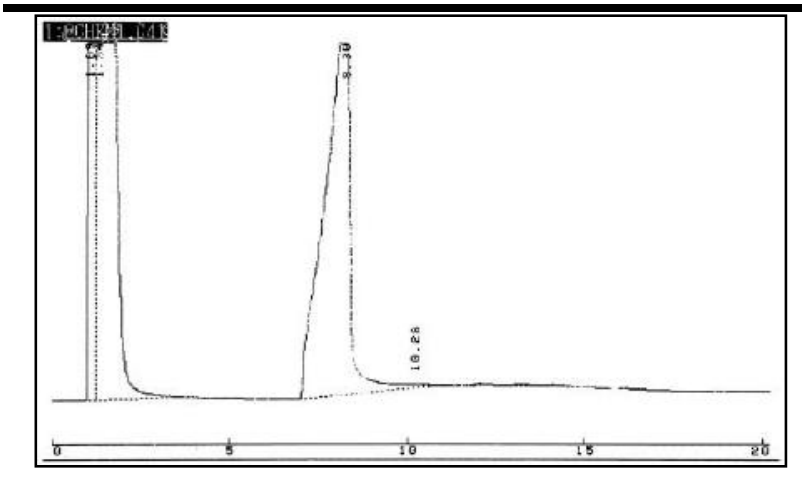

Octanoic

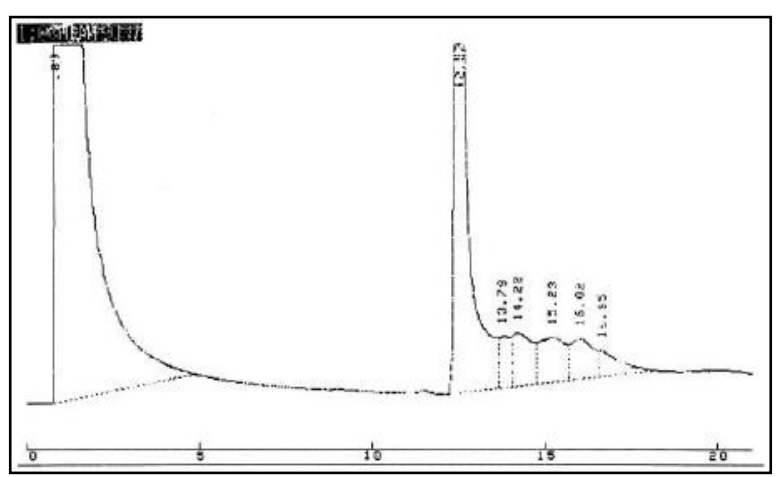

Lauric

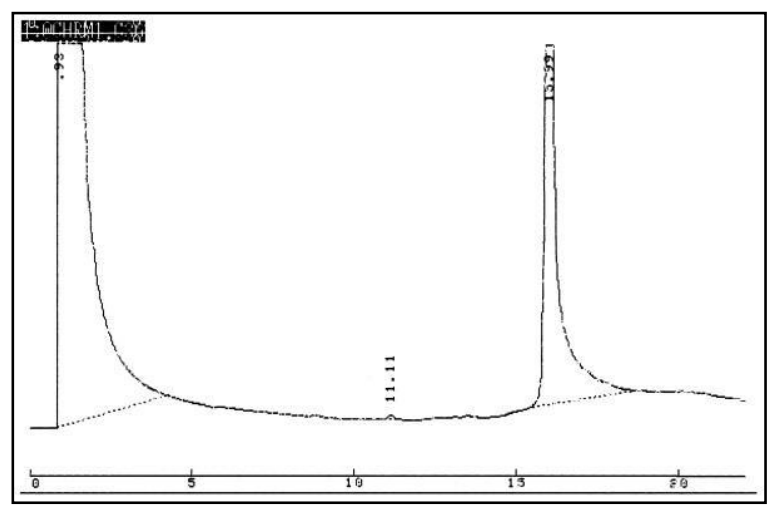

Palmitic

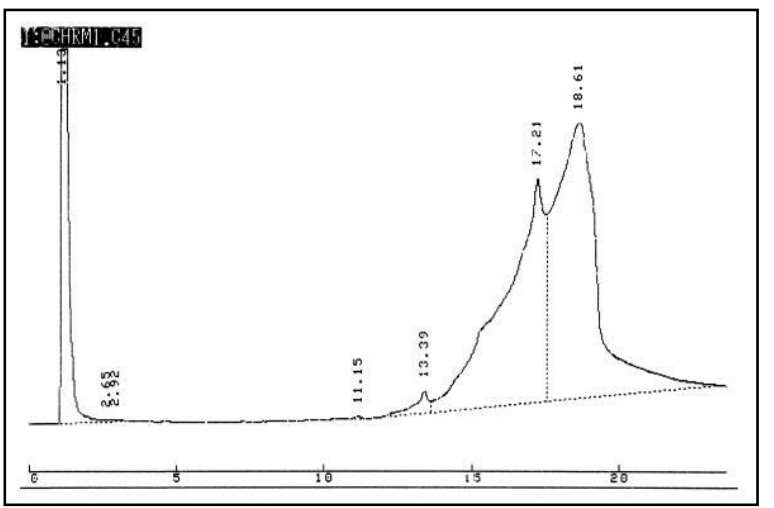

Oleic

Fig.2: GLC chromatograms of standard fatty acid compounds.
Table.2: HPLC analysis of amla extracts of phenolic compounds.

\begin{tabular}{|c|c|c|c|c|}
\hline \multirow{2}{*}{ Standard } & \multicolumn{3}{|c|}{ Phenolic compound } \\
\cline { 2 - 5 } Sample & \multicolumn{2}{|c|}{ Gallic acid } & \multicolumn{2}{c|}{ Hydroquinone } \\
\cline { 2 - 5 } & \multicolumn{2}{|c|}{2.081} & \multicolumn{2}{|c}{2.530} \\
\cline { 2 - 5 } & $\mathrm{R}_{\mathrm{t}}(\mathrm{min})$ & Area \% & $\mathrm{R}_{\mathrm{t}}(\mathrm{min})$ & Area \% \\
\hline Fraction $\mathrm{A}_{2} \mathrm{~F}_{2}$ & 2.048 & 2.345 & 2.537 & 96.901 \\
\hline
\end{tabular}

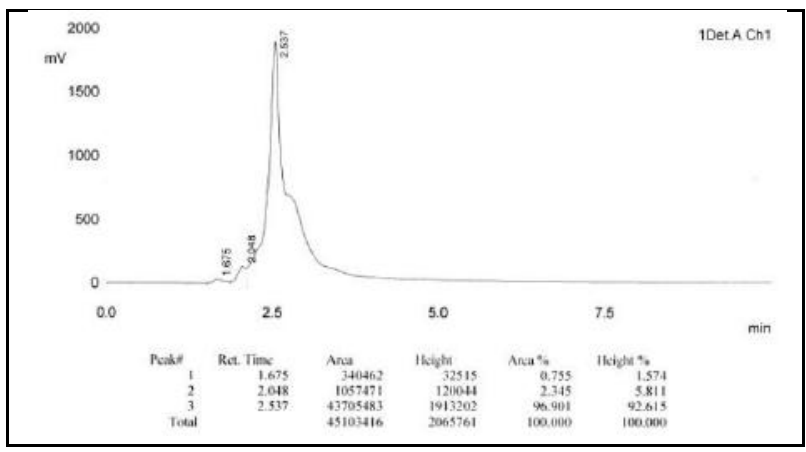

Fraction $\mathrm{A}_{2} \mathrm{~F}_{2}$

Fig.3: HPLC analysis of phenolic compounds present in amla extract.

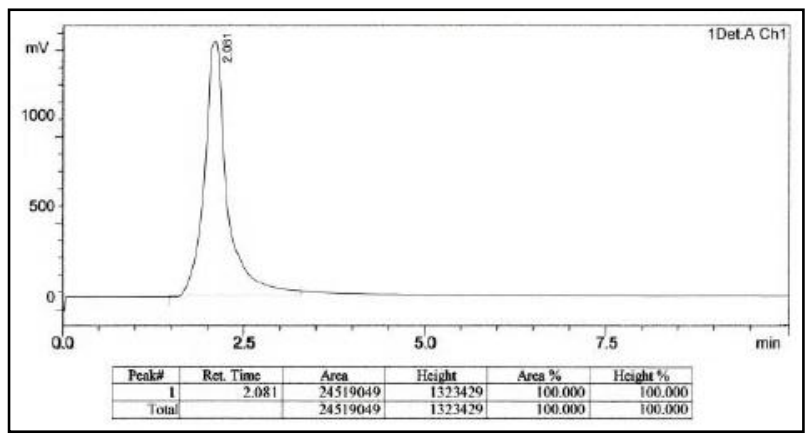

Gallic acid

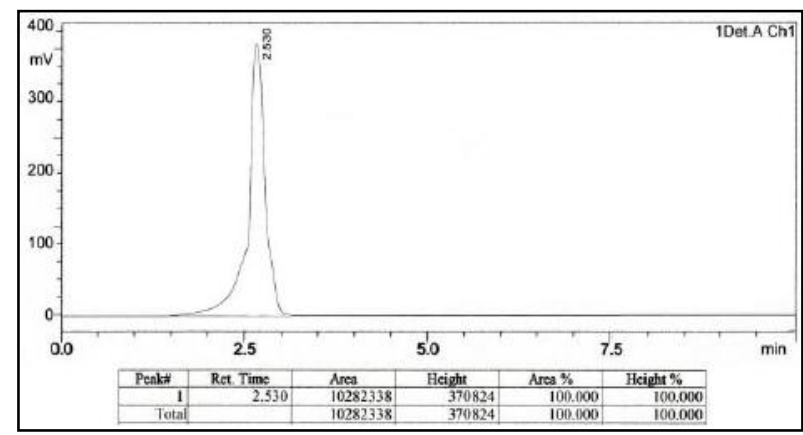

Hydroquinone

Fig.4: HPLC analysis of standard phenolic compounds. 
Table.3: Antibacterial activity of fatty acids and phenolic compounds of amla in some pathogenic bacteria (mm).

\begin{tabular}{|c|c|c|c|c|c|}
\hline \multirow{2}{*}{ Microbial species } & $\begin{array}{c}\text { Fatty acids extracts } \\
\text { Phenolic compound extracts }\end{array}$ & 200 & 100 & 50 & 25 \\
\cline { 3 - 6 } & $\mathrm{A}_{1} \mathrm{~F}_{2}$ & 25 & 20 & 19 & 15 \\
\hline \multirow{2}{*}{ Staphylococcus aureus } & $\mathrm{A}_{2} \mathrm{~F}_{2}$ & 25 & 20 & 16 & 15 \\
\cline { 2 - 6 } & $\mathrm{A}_{1} \mathrm{~F}_{2}$ & 24 & 20 & 16 & 10 \\
\hline \multirow{2}{*}{ Salmonella typhimurium } & $\mathrm{A}_{2} \mathrm{~F}_{2}$ & 22 & 20 & 19 & 14 \\
\cline { 2 - 6 } & $\mathrm{A}_{1} \mathrm{~F}_{2}$ & 27 & 20 & 15 & 11 \\
\hline \multirow{2}{*}{ Escherichia coli } & $\mathrm{A}_{2} \mathrm{~F}_{2}$ & 26 & 15 & 11 & 9 \\
\cline { 2 - 6 } & \multicolumn{4}{|c}{}
\end{tabular}

Table.4: Antibacterial activity inhibition zone ( $\mathrm{mm}$ ) using the standard antibiotics.

\begin{tabular}{|c|c|c|c|}
\hline Bntibiotics & Sacteria & Salmonella typhimurium & Escherichia coli \\
\hline Gentamicin (CN) $10 \mathrm{meg}$ & 21 & 19 & 25 \\
\hline Amikacin (Ak) $10 \mathrm{meg}$ & 15 & 15 & 16 \\
\hline Ciprofloxacin (cip) $10 \mathrm{meg}$ & 24 & 18 & 26 \\
\hline
\end{tabular}

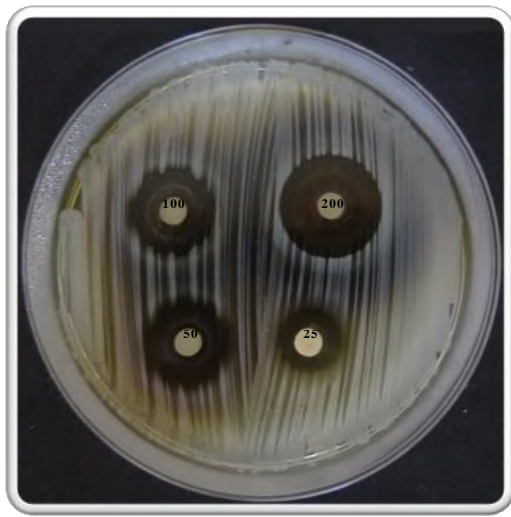

1. Effect of $\mathrm{A}_{1} \mathrm{~F}_{2}$ on Staph. aureus

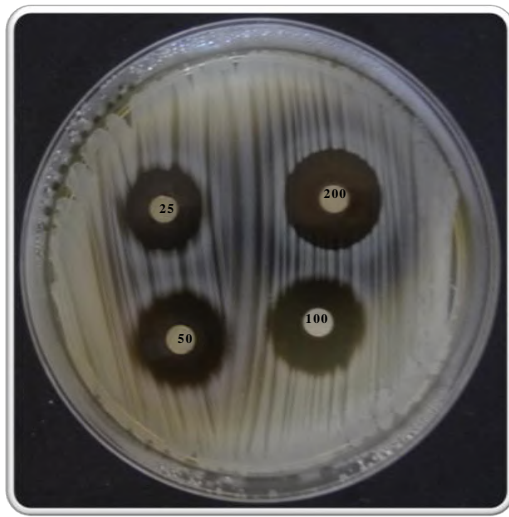

2. Effect of $\mathrm{A}_{2} \mathrm{~F}_{2}$ on Salmonella typhimurium

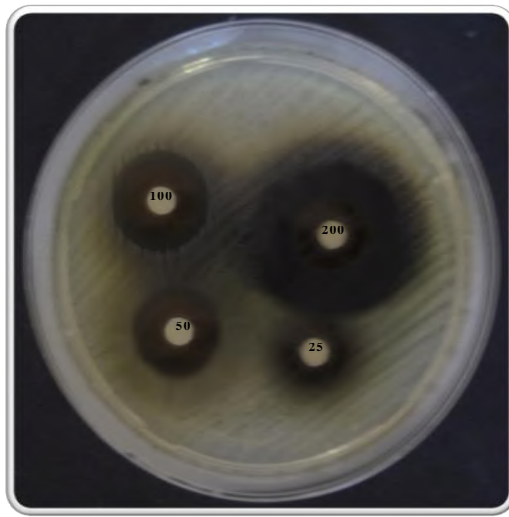

3. Effect of $\mathrm{A}_{1} \mathrm{~F}_{2}$ on E. coli

Photos 1-3. Antibacterial activity of some fatty acids and phenolic compounds in amlaextracts on bacteria under study.

\section{REFERENCES}

[1] Priya G,Parminder N and Jaspreet S, 2012. Antimicrobial and antioxidant activity on Emblicaofficinalis seed extract. IJRAP. 3(4): JulAug.

[2] Sairam, K,Rao CV, Dora BM, Vijay KK, Agarwal VK and Goel RK, 2002. Antiulcerogenic effect of methanolic extract of Emblicaofficinalis. An experimental study. Journal of Ethnopharmacology. 82: $1-9$.

[3] Rajkumar N,Shanthi G,SheelaVShand Selvakumar S, 2014. Antimicrobial effect of Emblicaofficinalis and cayratipedata against helicobacter pylori. Int. J of Allied Med. Sci. and Clin. Research. Vol. 2(4): 453-458.

[4] Arora A, Kumar I,Sen R and Singh J, 2011. Emblicaofficinalis (Amla): Physco-chemical and fatty acid Analysis from Arid Zone Rajasthan. International Journal of Basic and Applied Chemical
Sciences ISSN: 2277-2073 (Online) Vol.

October-December, PP. 89-92.

[5] Bansal V, Sharma A,Ghanshyam C and Singh ML, 2014. Rapid HPLC Method Development for Determination of Vitamin C, phenolic acids, Hydroxycinnamic acid and Flavonvids in Emblicaofficinalis Juice, Journal of Liquid Chromatography \& Related Technologies, 23 November, At: 16:40.

[6] Aruther I Vogel, 1972. Practical organic chemistry including qualitative organic analysis $3^{\text {rd }}$ edition. 445.

[7] Al-Kaisy MT,Hadwan HA,Saleh HM and Hussen AK, 1991. Determination of citric and oxalic acids in fermented solutions of Aspergillusniger by gas liquid chromatography. Iraqi: J. Microbiol. Vol. 3: 170-177.

[8] Harborne JB, 1998. Phytochemical Methods, London: Chapman and Hall, 60-66. 
[9] Bauer AW, Kirby WMM,Sherns JC and Turch M,1966. Antibiotic susceptibility testing by a standardized single disc method. Am. J. Clin. Pathol. 45: 493-496.

[10] Adam PO, 2006. Antibacterial activity of aqueous and ethanol extracts of the stem bark of Alsoniaboonei and Morindalucida. Sci. Res. Essaya. 1(2): 50-53.

[11] MohammadAsif, 2011. Health effects of omega 3.6.9 fatty acids: perillafrutesceus is a good example of plant oil orient oharm. Exp. Med. 11(1): 51-59.

[12] Okpako E and Ajibesin KK, 2015. Antimicrobial Activity of Celosia argentea L. Amarathaceae. American Journal of Research Communication. Vol. 3(5).

[13] Agarwal M, Kumar A,Gupa R and Upadhyaya $\mathrm{S}$,2012. Extraction of polyphenol, Flavonoid from Emblicaofficinalis\&Citurnslimor,CucumisSativus and Evaluation of their Antioxidant Activity. Oriental Journal of Chemistry ISSN: Vol. 28. pg. 993-998.

[14] Nitiema LW,Savadogo A,Simpore J,Diamon D and Traore AS, 2012. In Vitro Antimicrobial Activity of some Phenolic Compounds (Coumarin and Queretin) Against Gastroenteritis Bacterial Strains. International Journal of Microbiological Research. 3(3): 183-187.

[15] Karon D,Dicko MH,Simpore J and Traore AS, 2005. Antioxidant and antibacterial activities of polyphenols from ethnomedicinal plants of Butkina Faso. Afr. J. Biotechnol. 4: 823-828.

[16] Falleh H, Ksouri R,Chaieb K,Karras-Bouraoni N,Trabelsi N,Boullaaba M and Abdelly C, 2008. Phenolic Composition of CynaraCardunculus L. organs and their biological activities C.R. Biologies. 331: 372-374.

[17] Zongo C,Savadogo A,Somda KM,Kondon J and Traore AS, 2011. In vitro evaluation of the antimicrobial and antioxidant properties of extracts from whole plant of Alternantherapungens H. B. \& K. and leaves of CombretumSericuenm G. Don. International Journal of phytomedicine. 3: 182-191. 